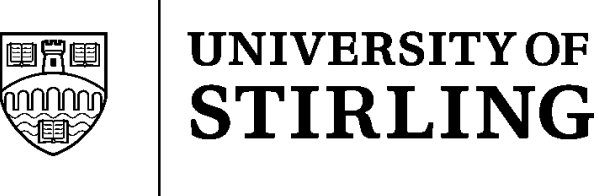

\title{
Operating lease finance in the UK retail sector
}

\author{
Alan Goodacre*
}

\begin{abstract}
The paper documents the importance of leasing in the UK retail sector and estimates the potential balance sheet impact of new accounting proposals to bring all leases onto lessees' balance sheets. Off-balance sheet operating leases are shown to be a major source of finance, and far more important (3.3 times higher) than onbalance sheet long-term debt; by contrast, finance leases are immaterial. Operating leased assets, the major part of which is 'land and buildings' (98\%), represent a significant proportion (28\%) of reported total assets. Capitalisation of operating leases would have a major impact on nine key performance ratios and would alter the ranking of companies markedly. The findings suggest that operating leases need careful consideration is estimating retailers' financial risk, in comparing cross-national performance and in research studies of capital structure decisions.
\end{abstract}

Keywords: leasing; operating leases; off-balance sheet finance; financial ratios; lease accounting.

\footnotetext{
* Alan Goodacre

Dept. of Accounting, Finance and Law

University of Stirling

Stirling FK9 4LA

Tel: $\quad 01786467291$

e-mail: Alan.Goodacre@stir.ac.uk).
}

\section{Acknowledgements}

The financial support of the University of Stirling Faculty of Management Research Fund is gratefully acknowledged. The author also wishes to thank Leigh Sparks and Steve Burt for helpful input and encouragement during the research. 


\section{Operating lease finance in the UK retail sector}

\section{Introduction}

The financial performance of UK retailing companies has attracted considerable attention from the press, politicians and from academics; of particular concern has been the potential abuse of market power, especially in food retailing. The research focus has been mainly on cross-national comparison of reported profits and margins (O'Riordan 1993; Parienté 1994; Burt and Sparks 1997). While the relative importance of debt and equity finance has been identified as contributing to cross-national performance differences, the financing of retail companies has received relatively sparse attention in the literature (but see Hutchinson and Hunter 1995; McCaffery et al. 1997) and the role of leasing has been largely ignored.

The collapse in 2002 of major international firms Enron and WorldCom is a timely reminder of the potential for accounting information to mislead investors and other stakeholders. In particular, the use of off-balance sheet finance can lead to gross distortion of the debts of a business. Leasing represents one such form of off-balance sheet financing, and is an issue that accountants have struggled to come to terms with; indeed the lease accounting standard in the US was voted the 'worst accounting standard' by a group of leading accountants (Reither 1998). In seeking to rectify the problem, accounting standard setters have made some radical proposals, which endeavour to bring all leases on to lessee companies' balance sheets. The purpose of the present paper is to document in a systematic way, for the first time, the importance of leasing in the UK retail sector and to estimate the potential balance sheet impact of the new accounting proposals. The paper makes a significant contribution to our understanding of the financing of retail companies.

The remainder of the paper is structured as follows. After a discussion of the current and proposed methods of accounting for leases, section two provides a review of relevant literature on retail finance and on estimating the effect of lease capitalisation. Section three outlines the methods employed in the current study, including sample and data collection procedures. The results and discussion are presented in section four and are followed by a summary and conclusion.

\section{Accounting for leases: current treatment}

In the UK, leasing is currently governed by accounting standard SSAP 21 'Accounting for leases and hire purchase contracts', which was issued in 1984 (ASC 1984). The standard identifies two types of lease and requires a radically different accounting treatment for each. A lease that transfers to the lessee substantially all the risks and rewards of ownership is a finance lease and is treated as an 'in substance' purchase by the lessee and sale by the lessor. Accordingly, an asset is shown on the lessee's balance sheet at the present value of the minimum lease payments and a corresponding liability is recognised. On the other hand, a lease which does not transfer substantially all the risks and rewards of ownership to the lessee is deemed to be an operating lease. Under an operating lease the whole of the leased property is treated as an asset of the lessor and the lessee simply recognises the rental payments as an expense, with limited additional footnote disclosure of future lease rental commitments. Internationally, other existing leasing standards such as International Accounting Standard 17 (revised 1997) and FAS 13 in the USA are based on similar concepts to SSAP 21 in relation to distinguishing finance leases from operating leases. 
The accounting issue can be illustrated by looking at some specific property transactions carried out by J Sainsbury plc. In two separate transactions in 2000, the company undertook the sale and leaseback of 26 of its food retail superstores for $£ 550 \mathrm{~m}$. The sales increased profit by $£ 133 \mathrm{~m}$ and committed the company to making annual lease rentals of $£ 43 \mathrm{~m}$, increasing at $1 \%$ per annum, for 23 years. The company argued that the long-term occupation of these core properties was secured and that it retained an interest in the potential upside value of the properties (Sainsbury 2000a, 2000b, 2000c, 2001). The sale and leaseback itself had obvious commercial advantages. The company had additional cash of $£ 550 \mathrm{~m}$ to develop the business and enjoyed a significant positive impact on reported profit. However, it is the accounting treatment of the leases which is of special interest here. Sainsbury (presumably, with the agreement of its auditors) judged that the lease contract with the new owner of the properties did not transfer substantially all the risks and rewards of ownership back to Sainsbury and so accounted for the leases as operating leases. Given the described circumstances this was probably a marginal decision, but one in conformity with generally accepted accounting principles, as currently defined. The difference that this decision has on Sainsbury's balance sheet and profit and loss account is demonstrated in Table 1. The actual operating lease treatment for the first year after the sale and leaseback is shown in column A, with column B showing what would have happened if the new leases had been accounted for as finance leases.

\section{$<$ TABLE 1 here $>$}

Under 'finance' leasing, the $£ 550 \mathrm{~m}$ properties would be 'capitalised' on the balance sheet and like any other fixed assets would be depreciated (here over the life of the lease). Similarly the total liability to make future lease rental payments would be recorded initially, reducing over time as 'capital' is repaid. The accounting issue is one of presentation and does not affect the cash position (the payment of $£ 43 m$ rental). In the profit and loss account, depreciation of $£ 24 \mathrm{~m}$ would be charged against operating profit rather than the $£ 43 \mathrm{~m}$ lease rental, so operating profit would actually be $£ 19 \mathrm{~m}$ higher. However, the interest element of the rental ( $£ 36 \mathrm{~m}$ ) remains to be charged giving a net reduction of $£ 17 \mathrm{~m}$ in profit before tax. ${ }^{1}$ In the early years of a lease, as here, the profit before tax is lower (because depreciation plus interest is more than the operating lease rental). This situation reverses in the later years of the lease (after year 13 here) as the interest element of the rentals falls.

The attractions of the operating lease treatment to the company are clear, equivalent to buying and having use of the property assets without having to show any related borrowings used to finance the purchase. The effect on performance and risk measures such as gearing can be large. For example, in Sainsbury's case the reported gearing (net debt to equity) for 2001 was just 17\%; if the leases had been on balance sheet, the gearing would have been significantly higher, though still modest, at $29 \%$.

\section{Accounting for leases: proposed treatment}

Since the introduction of SSAP 21, there has been a considerable growth in the use of offbalance sheet operating leases (Goodacre and Beattie 1999) and this has encouraged accounting standard setters to review the working of the standard and to propose major changes. The main thrust of the proposals is to bring all leases on to lessee companies' balance sheets. In effect, all leases would be treated in a similar manner to 'finance' leases and, as the Sainsbury case illustrates, this has the potential to have a major impact on reported debt levels and financial risk measures. The recent accounting developments are outlined in this section. 
In 1996, a group of standard setters from the UK, US, Australia and New Zealand, together with the International Accounting Standards Committee (collectively known as the G4+1), published a special report entitled Accounting for Leases: A New Approach (McGregor 1996). This identified several fundamental deficiencies in current lease accounting standards. First, they omit material assets and liabilities arising from 'off-balance sheet' operating lease contracts. Second, marginal differences in contractual terms can result in one lease being claimed as a finance lease and another as an operating lease and thus similar transactions do not receive the same accounting treatment. Third, the 'all or nothing' approach to the capitalisation of leased assets does not adequately reflect modern complex transactions. The report went on to explore a conceptual approach to lease accounting, recommending that new standards should be developed that would remove the distinction between finance leases and operating leases and would require lessees to recognise as assets and liabilities all material rights and obligations arising under lease contracts.

More recently, the UK Accounting Standards Board (ASB) published a discussion paper Leases: Implementation of a New Approach (ASB 1999), in which the G4+1 develops further the approach outlined in the special report. This recommends that all leases should be reflected in financial statements in a consistent manner and it explores the principles that should determine the extent of the assets and liabilities that lessees and lessors would recognise under leases. Under the recommended approach, at the beginning of a lease the lessee would recognise an asset and a liability equivalent to the fair value of the rights and obligations that are conveyed by the lease (usually the present value of the minimum payments required by the lease). Thereafter, the accounting for the lease asset and liability would follow the normal requirements for accounting for fixed assets and debt. The lessor would report financial assets (representing amounts receivable from the lessee) and residual interests in the leased assets separately. The principles for accounting for more complex features of lease contracts including renewal options, contingent rentals, residual value guarantees and sale and leaseback transactions are also examined.

All the G4+1 organisations have published the discussion paper in their own jurisdictions but further progress on accounting standards is likely to be slow. Even in the UK where there has been strong commitment to the project, the ASB has acknowledged that 'because of the complexity of the issues arising and the concerns expressed by some respondents, it will take some time for the Board to consider all of the points raised' (ASB 2001).

The proposals are controversial and have already generated significant negative response from some who fear that there will be major economic consequences if the proposals are adopted. For example, the British Retail Consortium attacked the proposals, the acting director-general being reported as suggesting that 'retailers' balance sheets will become weakened, which would have an adverse impact on investor confidence and hence hamper retailers' expansion plans' (Retail Week 2000). The Finance \& Leasing Association argued that the proposals 'would have complex and dramatic effects on the financing of British business' and 'will be damaging to many companies' balance sheets' (Finance \& Leasing Association 1999). KPMG suggested that 'there seems little merit in replacing one set of arbitrary rules with another' (KPMG 2000). The real estate industry is also concerned about the impact on the sector. It has argued that the proposals "will increase the occupiers reluctance to enter into long term commitments, leading to a further and more rapid demand for flexible arrangements' and that in the period of uncertainty surrounding discussion of the proposals 'decision making will be difficult and this may create a substantial slowdown in the letting market' (Investment Property Forum 1999). 


\section{Literature}

The potential abuse of market power has provided the context for several studies that compare reported profits and margins across different countries (O'Riordan 1993; Parienté 1994; Burt and Sparks 1997). For example, Burt and Sparks (1997) argued that, for proper interpretation of differences in reported performance, it is important to consider differences in accountancy practices, costs structures, management structures and control, and the environmental context. They highlighted particular accounting differences relating to the amortisation of goodwill, depreciation of store assets, and the capitalisation of interest on store development. Differences in cost structures included cross-national disparity in the buying power of retailers, supplier payment terms, and costs of distribution, personnel and property.

Within these studies, cross-national differences in company financial structure have been recognised as contributing to differences in reported (rather than real) performance (Parienté 1994; Burt and Sparks 1997). However, there are relatively few studies that focus directly on the financing of retail companies. Hutchinson and Hunter (1995) used an OLS regression approach to examine the capital structure decision of UK retail companies and found that the determinants of capital structure were broadly similar to those observed in other sectors. Firms with higher levels of debt (higher gearing) generally had more tangible assets (to act as collateral) had higher stock market measures of firm risk and had a national (rather than regional) profile. Gearing was inversely associated with profitability and also with growth opportunities. In contrast with prior results for other sectors, they did not find that larger firms had higher gearing. McCaffery et al. (1997) provided a synopsis of some of the main issues in corporate finance and reported the views on financial practice of a small sample of retail company financial managers. Managers responding to the survey believed that capital structure (gearing) impacts on a company's value (i.e. that financing policy can be used to enhance the benefits deriving from real investments). They considered that a company should pursue a target level of gearing, and that this level should be between $40-50 \%$, on average. Further, they agreed that a company should leave unused some of its debt capacity to provide 'financial slack' for use in times of financial difficulty. Retained profit was regarded as the most important source of finance followed by short-term bank debt, then long-term debt. Dividend policy, investment appraisal techniques and working capital policies were also explored together with managers' views on performance measures. For the latter, managers considered that the price earnings (PE) ratio and return on capital employed were most important, closely followed by return on assets and return on equity; the cash ratio was also viewed as important. Perhaps surprisingly, asset turnover (sales/total assets) and interest cover (times interest earned) received less emphasis.

Several prior studies have investigated the effect of lease capitalisation on ratio performance measures, though not specifically within the retail sector. In an early study, Nelson (1963) examined the impact on the debt-equity ratio of eleven US companies and found a significant change in the rankings of the companies after capitalisation. In the UK, Ashton (1985) estimated the effect of finance lease capitalisation on six ratios for 23 companies and found that only the gearing ratio would be affected significantly and that correlations between pre- and post-capitalisation ratios were high. However, his conclusion that interfirm comparisons of performance would not be affected significantly by capitalisation may be subject to sample selection bias. Imhoff, Lipe and Wright (1991) (hereafter ILW) developed a method for the constructive capitalisation of operating leases and used this to estimate the impact of capitalisation on two ratios (return on assets and debt to equity) for 
14 US companies (seven matched pairs, selected to represent high and low operating lease use). They found material differences in the ratios for both 'high' and 'low' lessees. In a subsequent paper (Imhoff et al. 1997), they explored income effects of operating lease capitalisation and indicate that the effects can be both substantial and unpredictable in direction. The retail investment analyst team at Dresdner Kleinwort Benson (hereafter $\mathrm{DKB}$ ) produced a research report highlighting the high level of gearing that would result from capitalising operating leases (Dresdner Kleinwort Benson 1998). This was based on a detailed study of 27 large UK general retail companies and showed that 'net debt would be in excess of $100 \%$ of equity market capitalisation in many cases, .... exposing shareholders to extremely volatile returns'.

While these five studies are all based on small samples, Beattie, Edwards and Goodacre (1998) (hereafter BEG) used a large random sample of 232 UK listed companies to estimate the potential impact of capitalising lease contracts currently classified as operating leases. For 1994 , they found that the average operating lease liability was $£ 51 \mathrm{~m}$, split between $£ 8 \mathrm{~m}$ short-term and $£ 43 \mathrm{~m}$ long-term, with the latter representing approximately $39 \%$ of on-balance sheet long-term debt, on average. There was a wide variation across different sectors ranging between 14\% (general industrial) and 69\% (services) of long-term debt, reflecting the variation in the use of operating lease finance. The $£ 43 \mathrm{~m}$ operating lease liability compared with an average reported liability for finance leases of $£ 4 \mathrm{~m}$, implying that operating leases were 13 times as important as finance leases. They also found that performance measures such as profit margin and gearing would be significantly affected by operating lease capitalisation. On average, operating profit margin increased from $8.7 \%$ to $9.8 \%$ and there was a dramatic increase in the gearing ratio (net debt to equity) from $20 \%$ to $72 \%$ for the sample as a whole and from $24 \%$ for $141 \%$ in the services sector. Further, the relative ranking of companies changed markedly both within and across different sectors. They concluded that 'significant changes in the magnitude of key accounting ratios and a major shift in company performance rankings suggest that interested parties' decisions and company cash flows are likely to be affected' by a policy change requiring operating lease capitalisation.

Prior research suggests that indebtedness levels and performance measures in the retail sector are likely to be significantly affected if the G4+1 proposals are adopted as an accounting standard. The present study investigates whether the empirical evidence for a large sample of both small and large UK retail companies is consistent with these expectations.

\section{Methods}

This section provides details of sample selection, justification of the chosen accounting ratios and their definitions, and an outline of the comparison methods used. It also explains the approach used to estimate the unrecorded operating lease assets and liabilities.

\section{Sample selection and data}

A list of food retail and general retail companies was extracted from Datastream and crosschecked to FT Sequencer database and yielded 106 companies. Of these, data could not be found for four companies leaving a total of 102 for further analysis. Basic data on sales, profits, assets and liabilities were extracted from Datastream for the period 1994 to 1999. Operating lease data is not available in computerised databases at a level of sufficient detail for the constructive capitalisation process. Thus all operating lease data were extracted manually from company microfiches, obtained from the Registrar of Companies, or from 
hard-copy published accounts. Data on finance leases were also collected in this way for consistency and to improve reliability.

\section{Impact of capitalisation on key accounting ratios}

Ratios are widely used as decision tools by users of financial statements such as investors and loan officers. To assess the likely decision impact of incorporating operating leases on balance sheet, nine key performance ratios were investigated. These ratios were an operating margin, three return on capital measures, asset turnover, income gearing and three capital gearing measures. The specific ratio measures were chosen to reflect use and to allow comparison with previous studies. Their definitions and the expected directional effect of accounting for leases as finance leases, rather than operating leases, is summarised in Table 2.

$<$ TABLE 2 here >

In some contexts performance is judged against an absolute benchmark. For example, loan covenant restrictions may focus on a maximum gearing level or a minimum level of interest cover (or both). Executive compensation schemes may, in part, be based on achieving a particular level of profitability (e.g. return on assets, or return on equity). Consequently, changes in the actual performance measures are important so the differences between preand post-capitalisation ratios are investigated here.

In other decision contexts, such as investment decisions made by investors, the relative performance of companies may be more relevant (i.e. company rankings). The impact of operating lease capitalisation on relative performance is assessed by measuring the correlation between pre- and post-capitalisation ratios; both Spearman rank and Pearson correlation coefficients are reported and discussed.

\section{Operating lease capitalisation procedure}

The rights to use assets acquired under operating lease contracts are not currently recognised on the balance sheet of UK companies; rather, aggregate information about such contracts is disclosed by way of a note to the financial statements. The information disclosed is a schedule of next year's operating lease payments analysed by asset category (i.e. 'land and buildings' and 'other') and by lease expiry date (i.e. leases expiring within one year, between one and five years, and after five years).

Estimation of the present value of the unrecorded lease liability requires assumptions to be made regarding the appropriate interest rate and the average remaining lease life. Estimation of the present value of the unrecorded lease asset requires further assumptions to be made regarding the average total lease life and the depreciation method. Finally, the impact of capitalisation on deferred tax requires an assumption to be made regarding the appropriate tax rate.

In the present study, the 'constructive capitalisation' procedure followed the basic method outlined by BEG (1998), which derived from ILW (1991). Effectively, the method incorporates company-specific assumptions in respect of the average remaining and total life of the company's lease portfolio, the lease asset/liability proportion and an effective tax rate. It also distinguishes between asset categories and lease expiry categories, with separate calculations of remaining lease life and asset/liability proportions performed for each. ${ }^{2}$ 
Depreciation on the lease asset is assumed to be charged on a straight-line basis over the life of the lease.

BEG (1998) describe a rationale for adopting particular remaining and total lease life estimates for each lease expiry category (<1year/2-5years/>5years) of each asset type (land and buildings/other). ${ }^{3}$ The same estimates are used in the present study. One of the key assumptions, for example, is that leases of 'land and buildings' within the ' $>5$ years' expiry category have 16 years remaining of a total 25 year lease life. ${ }^{4}$

As the tax rate can vary considerably over time, an average tax rate for each company was calculated over the period 1994 to 1999. For companies reporting a loss in a particular year or with a negative tax charge (usually giving a negative tax rate), the tax rate was set to zero. To avoid distortions in the average tax rate, a small number ( 7 out of 483 firm-year observations) of outlier positive tax rates were set to $50 \%$.

There is considerable debate as to the appropriate interest rate to use in the discounting process. Various possibilities have been suggested including a single discount rate to be applied by all companies, a company-specific borrowing rate that will reflect the credit risk of the company, and a lease-specific rate (rate implied by the terms of the lease) that will reflect the lessor's risks as well as the credit risk of the lessee. The main focus of the present study is to report average aggregate effects of leasing in the retail sector so a relatively simple approach is adopted. Land and buildings represent the major asset category for operating leases and these tend to be relatively long contracts, often of 15-50 years. The assumption implicit in the estimation of the present value of lease liabilities is that land and building contracts were, on average, of 25 years duration and started 9 years before the accounting period (i.e. remaining lease life $=16$ years). The average interest rate implied in 10-year UK government stock over the period $1984-1999$ was $8.44 \%$, so a single risk-free discount rate of $8.5 \%$ is used for all companies. In view of the fall in interest rates over the 1990s this may lead to somewhat conservative estimates of operating lease liabilities and impacts. The sensitivity of the results to this interest rate assumption is tested by varying the discount rates by $\pm 1.5 \%$.

A further issue relates to the treatment of rentals that rise in line with prices. The most common, and important, occurrence is in the upward-only rent review lease, typical of many commercial property leases in the UK. The G4+1 consensus is that the likely future price changes should be estimated at the start of the lease contract and incorporated in the calculation of the present value of minimum lease payments. This treatment is theoretically sound since a nominal interest rate (which incorporates the market's inflation expectations) is used to discount the cash flows. However, the ASB dissented from this view on the grounds that estimates of future price increases would be unreliable. The results presented here are based on the ASB view, with no anticipation of future price increases.

\section{RESULTS}

\section{Operating lease assets and liabilities}

Table 3 provides a summary of the estimated average values of operating lease assets and liabilities within the food retail and general retail sectors, and over all retail companies, for 1999. The estimated figures for J Sainsbury plc are also provided for comparison. An indication of the scale of operating leases is provided by making comparisons with long- 
term (on-balance sheet) debt, total assets and finance lease liabilities. Estimates of average income effects are also presented.

$<$ TABLE 3 here >

The overall mean (median) level of operating lease liability in the retail sector for 1999 is estimated to be $£ 234 \mathrm{~m}$ ( $£ 60 \mathrm{~m}$ ), of which $£ 12 \mathrm{~m}$ is due within one year and $£ 222 \mathrm{~m}$ is due after more than one year. The large mean-median difference reflects the positively skewed size distribution of companies within the sector. Companies in the general retail sub-sector have slightly smaller operating lease liabilities (mean $=£ 222 \mathrm{~m}$ ) than those in food retailing (mean $=£ 287 \mathrm{~m})$. The scale of these off-balance sheet liabilities can be judged by comparison with the on-balance sheet long-term debt. On average, retailing companies have a mean debt level of $£ 67 \mathrm{~m}$ but there is a large difference between the two sub-sectors, with food retailers having $£ 173 \mathrm{~m}$ compared with $£ 41 \mathrm{~m}$ for general retailers. The lease-debt ratio (long-term element of operating lease liabilities/on-balance sheet long-term debt) is 1.6 for food retailers, 5.1 for general retailers and 3.3 overall. These figures are based on the mean sector and sub-sector values of operating lease liability and debt. To appreciate the importance of operating leases at the individual company level, median ratios were estimated excluding those companies with zero long-term debt. The median lease-debt ratios were 2.9, 9.1 and 6.6 for food, general and the sector overall. ${ }^{5}$ Thus, in the retail sector, and particularly the general retailing sub-sector, operating lease finance is considerably more important than long-term debt. This is of major significance in the assessment of financial risk.

The level of finance lease liabilities is relatively small in the retail sector with mean liabilities of $£ 10.8 \mathrm{~m}$ (food), $£ 5.4 \mathrm{~m}$ (general) and $£ 6.4 \mathrm{~m}$ (all); the median finance lease liabilities are very small (all less than $£ 0.1 \mathrm{~m}$ ). The relative unimportance of finance leases is clear from the operating lease/finance lease ratios of 27 (food), 41 (general) and 37 (all); i.e. operating lease liabilities are, on average, approximately 37 times the level of finance leases.

On the asset side, mean total operating leased assets are estimated to be $£ 182 \mathrm{~m}$, the major part of which is land and buildings $(£ 178 \mathrm{~m}, 98 \%)$ rather than plant and equipment $(2 \%)$. These off-balance sheet assets represent a major proportion of reported total assets with estimates, based on overall means, of $16 \%$ for the food sub-sector, $37 \%$ for general and $28 \%$ overall. The equivalent median figures based on individual company ratios are higher at $34 \%, 55 \%$ and $52 \%$ respectively. Thus, operating leased assets are extremely important in the retail sector, and their current exclusion from the balance sheet has the potential to distort return on asset type performance measures.

The effect of operating lease capitalisation on operating profit (EBIT) will be positive since expenses will include depreciation rather than the operating lease rental (and depreciation < OLR). The approximate effect in the retail sector is that the mean operating profit would increase by $14 \%$ (food), 30\% (general) and 23\% (all). The impact on net profit (profit after tax) depends on the stage reached in the life of the lease portfolio. In the early years, net profit is reduced (depreciation + interest > OLR) and this is reversed in the later years of a lease contract (or portfolio). If investment in operating leased assets is growing (as in the retail sector) then companies will generally be in the 'early years' period. Based on this assumption, the reduction in mean net profit is estimated to be $4 \%$ (food), 9\% (general) and $7 \%$ (all); median net profit reductions based on individual company data are similar. Thus, the average impact on net profit is relatively small, but this average does mask the fairly 
drastic effect that would be felt by some companies, notably those with very high levels of operating leases or those with low levels of reported profit.

\section{Impact of capitalisation on performance ratios}

Table 4 reports the results from assessing the impact of operating lease capitalisation on performance ratios in the retail sector for 1999. ${ }^{6}$ To reduce the impact of outlier observations, median rather than mean ratios are reported. The ratios are calculated precapitalisation based on figures in the published financial statements (termed pre in the table) and post-capitalisation. The difference between medians is also reported together with a two-tailed test of whether the samples are drawn from populations with the same medians and the same continuous distribution (the Wilcoxon signed ranks test). ${ }^{7}$ Two-tailed t-tests of mean differences were also carried out (but not reported here) and, except where noted, similar results were obtained. Note 6 to table 4 provides illustrative ratios for J Sainsbury plc.

$<$ TABLE 4 here $>$

For the general retail sub-sector, significant differences were observed for all nine ratios (at the $1 \%$ level). ${ }^{8}$ The median operating margin increased (from $8.1 \%$ to $11.5 \%$ ), ROA decreased, asset turnover decreased and the three gearing measures all increased; for example, net debt to equity increased from $17 \%$ to $157 \%$ after capitalisation of operating leases. For the three ratios with indeterminate directional expectations, ROE increased, ROCE decreased and interest cover decreased. For food retailers, five of the nine median ratios were significantly different (at the $1 \%$ level), three of them (ROA, ROCE and interest cover) at the $5 \%$ significance level with just ROE not significant. ${ }^{9}$ For the retail sector as a whole, all ratios were significantly different following capitalisation of operating leases. Thus, a requirement to capitalise all operating leases would potentially have a major impact on ratio measures of operating performance. This could have important economic consequences in decision contexts where performance is judged against an absolute benchmark, such as loan covenant restrictions or executive compensation schemes.

An alternative view on the results is that they suggest that the off-balance sheet disclosure of operating leases is currently distorting reported company performance. Gearing is grossly understated. Many retail firms have large long-term commitments to make operating lease rental payments and this will lead to more volatile profits, higher risk that will also be reflected in more volatile equity returns. Return on capital employed type measures are often used to see whether a firm is creating value by earning above its cost of capital. As indicated above, high operating lease usage distorts such comparisons because the leased assets are currently excluded from the capital employed denominator. Thus, great care is needed in the assessment of company performance.

In some decision contexts (such as investment decisions made by investors) the relative performance of companies is more relevant. The impact of operating lease capitalisation on relative performance is assessed by measuring the correlation between pre- and postcapitalisation ratios. Both Spearman rank and Pearson correlation coefficients are reported in Table 5. Broadly similar results are obtained for food and general retailers. The ratios can be split roughly into three groups on the basis of the strength of pre- and post-capitalisation correlations. A group of four ratios have 'moderate to high' positive correlations (above 0.8 on one or both measures); these are the three return on asset measures and the profit margin. A group of three ratios have 'low' positive correlations (between 0.6 and 0.8 , but statistically significantly greater than zero); i.e. asset turnover, interest cover and the gearing ${ }_{I L W}$ measure. The two remaining gearing ratios, gearing ${ }_{\text {Ashton }}$ and net debt to equity, 
both have 'very low' correlations (less than 0.3 , statistically insignificantly different from zero $^{10}$ ). Thus, lease capitalisation will affect relative performance based on all nine ratios considered, but particularly on gearing measures.

The low correlations reflect the fact that there are considerable differences in the use of operating lease finance within the retail sector. Consequently, some companies have much higher levels of off-balance sheet assets and liabilities than others in the sector leading to more 'hidden gearing' and inflated return on asset measures.

$<$ TABLE 5 here >

\section{Comparison with other sectors}

Table 6 provides a comparison between the balance sheet effects for retail companies and the overall (across all sectors) and services sector results reported by BEG (1998). The retail figures are based on those companies from the current sample that existed in 1994 (the last year and focus of the BEG study); thus, this retail sub-sample suffers from survivorship bias. However, comparisons between 'new' and 'continuing' retail companies (not reported here) show that 'continuing' companies have lower usage of operating leases than 'new' companies. So, in view of the directional difference observed, survivorship bias is likely to reduce the reported differences.

$<$ TABLE 6 here $>$

The mean total operating lease liability within the retail sector companies in 1994 is estimated to be $£ 195 \mathrm{~m}, 1.9$ times higher than the services sector and 3.8 times higher than the overall level reported in BEG. The retail lease-debt ratio is 2.6 compared with 0.7 (services) and 0.4 (overall). A similar picture emerges for the operating lease asset, which for retail is $23 \%$ of total assets compared with $13 \%$ (services) and $6 \%$ (overall). These figures confirm prior expectations that retailers are heavy users of lease finance, much heavier than most other sectors (as suggested in Beattie et al. 2000a).

A comparison between changes in performance ratios for retail companies and those reported in two prior studies (BEG 1998 and ILW 1991) is given in Table 7. For consistency with the prior studies, the comparisons are based on mean ratios (rather than medians). While formal cross-study significance tests cannot be applied, the impact of operating lease capitalisation in the retail sector is clearly much greater than reported in these prior studies. For example, the changes in gearing ratios for retailers are between 4.7 and 8.6 times greater than the all-sector changes in the UK (BEG 1998) and the change in gearing $_{\text {ILW }}$ is 2.5 times greater than the average change reported for US companies (ILW 1991). These observations are consistent with the very heavy use of operating leases in the retail sector illustrated above and suggest that adjustments need to be made in any crosssectoral comparisons of performance.

$$
<\text { TABLE } 7 \text { here > }
$$

\section{Sensitivity analysis}

To test the inter-temporal stability of the findings, the basic analysis reported in Tables 3 through 5 was repeated for the four years 1994 through 1998 on several alternative bases. For illustrative purposes, the figures for all retailers based on a constant discount rate of $8.5 \%$ will be used. Across the retail sector as a whole, the estimated mean total operating lease liability varied between $£ 213 \mathrm{~m}$ (1994) and £229m (1997) compared with the $£ 234 \mathrm{~m}$ reported for 1999 in Table 3. The lease-debt ratio ranged from 2.94 (1994) to 3.91 (1997) 
compared with 3.32 in 1999 (Table 3). Across all years and all nine ratios for both subsectors and all retailers, the changes in median performance ratios following capitalisation were of the same sign, of similar magnitude and were all significantly different from zero. ${ }^{11}$ For example, the differences in net debt to equity varied between $+102 \%$ (1996) and $+152 \%$ (1997) compared with $138 \%$ in 1999 (Table 4). With minor exceptions, the pattern of correlations each year was consistent with that illustrated for 1999 in Table 5. Thus, the importance of operating lease finance and the impact of capitalisation seem to be stable over the time period covered here.

The sensitivity of the results to key assumptions was investigated using 1999 data. First, the base assumption of a common interest rate of $8.5 \%$ was varied by $\pm 1.5 \%$. Second, the base estimates for remaining (RL) and total lease (TL) lives were changed to more extreme, but still plausible, estimates. This only really affects leases in the category that expire after more than five years. One set of estimates places leases at an earlier stage in a long lease; for land and buildings $R L=22$ years, $T L=30$ years, for other assets $R L=9$ years, $T L=12$ years. The other set places leases at a later stage in a short lease; for land and buildings RL $=10$ years, $\mathrm{TL}=20$ years, for other assets $\mathrm{RL}=5$ years, $\mathrm{TL}=8$ years. The early stage/long lease combination tends to increase operating lease asset and liability and increase interest charge, thereby reducing profit; the opposite is true for the later stage/short lease combination.

For all four scenarios, all ratio differences were of similar size, in the same direction and had identical significance levels, with one or two minor exceptions caused by extreme outliers. These exceptions were for the changes to base estimate lease lives and just three ratios. The change in median ratio for ROCE in food retailers in the later stage/short lease scenario was of similar size, in the same direction but ceased to be significant at the 5\% level. No other median change was significantly affected. For changes in mean ratios, the ROE ratio was affected by extreme outliers and changed sign for general retailers in the early stage/long lease scenario. In the later stage/short lease scenario the gearing ILW ratio ceased to be significant and the net debt to equity ratio was only significant at the $5 \%$ level, both driven by extreme outliers (e.g. Harveys Furnishing had a post-capitalisation net debt to equity ratio of $20,298 \%$ !). In all cases, removal of the outliers led to results consistent with the original assumptions employed. Correlations between pre- and post-capitalisation ratios were all of similar magnitude to those observed for the original assumptions. In view of the minor changes, detailed results are not reported.

Further confidence in the estimation process can be gained by comparing results from the present study with those obtained by DKB (1998). 23 companies are common to both studies based on 1998 year-ends. The mean estimated lease liability in the present study was 8.4\% lower than DKB estimated for these same companies. However, the correlation between estimates was very strong $($ Pearson $=0.96$, Spearman $=0.98)$. The measure of agreement between the estimates in the present study, based only on publicly-available data, and those of DKB based on semi-privileged information is very encouraging.

One of the sample companies, WH Smith plc, voluntarily disclosed additional information about its operating lease liability in its financial statements for the year ending 31 August 1999. In particular, it reported that its total liability was $£ 700 \mathrm{~m}$ after discounting its future minimum operating lease commitments at a before tax weighted average cost of capital of $10.4 \%$. In the present study, using the standard common risk-free discount rate of $8.5 \%$, the estimated liability based solely on the SSAP 21 disclosures is $£ 832 \mathrm{~m}$. However, a large proportion of the difference relates to the application of an alternative principle in choosing 
the discount rate. Using the same discount rate in the present study would have given an estimated liability of $£ 750 \mathrm{~m}$, just $7 \%$ higher than the company disclosed figure.

The sensitivity analysis suggests that the results of this study are robust to the key assumptions incorporated in the operating lease capitalisation procedure. Comparisons of estimates from the present study with those based on more detailed knowledge of individual company circumstances further increases confidence in the reasonableness of the procedures adopted herein.

\section{Managers' response to lease capitalisation}

A major assumption in the paper thus far, somewhat unrealistic in the light of prior evidence, is that company management will not take any steps to mitigate the effect of capitalisation. Rather extremely, they might change their asset financing policies away from leasing, but this may not be possible, for example in obtaining access to 'land and buildings' assets. Alternatively, they might seek to modify lease contract terms to minimise the impact of capitalisation as illustrated by their switch from finance to operating lease contracts in response to the introduction of SSAP 21. Based on the current G4+1 proposals, a possible route focuses on the treatment of renewable leases. A lease may be written for a fairly short primary rental period with an option to renew the lease. Under the G4+1 proposals, the exercise of renewal options 'should not generally be anticipated' except where the fixed non-cancellable term is clearly unrepresentative of the period that the lessee is compelled to use the property (ASB 1999: 90-1). Thus, one way to mitigate the impact of lease capitalisation would be to use shorter primary lease periods (much shorter than current practice on 'land and buildings' contracts) with options to renew for further short periods; a similar effect can be achieved using break clauses in longer leases.

Obviously, this would not suit all circumstances. However, it is consistent with the trend towards lessees seeking shorter leases for purely commercial reasons, mainly reflecting lessees' need for greater flexibility in choosing and changing locations of retail outlets, for example (Nelson 1999; BPF/IPD 1999). These renewable short contracts are likely to shift risks from lessees to lessors since, for example, the lessor will now bear the risk that the lessee will not exercise the option to renew. This is most likely to happen when the attractiveness of the asset has reduced for some reason. When this is a general 'decline' in the future worth of the asset, rather than lessee-specific, then a significant cost (loss of value, difficulty in obtaining a new lessee or disposing of the asset) will be borne by the lessor. This risk shift will be of concern to lessors, some of whom will see it as a threat while others may recognise an opportunity for increasing returns to compensate for the extra risk.

A new set of calculations was undertaken to obtain a preliminary 'feel' for the change in impact if all company managers were to adopt this approach. For this, a simple but fairly radical assumption was made that all lease contracts (i.e., both 'other' and 'land and buildings' categories) would have a maximum term of 5 years. After an initial phase the average remaining life for these contracts would settle at about 3 years. A second assumption implicit in the calculations is that the value of the renewal option will be small and so can be ignored. For simplicity, any increase in lease rental required to compensate for the lessor taking on additional residual value risk is also ignored; this may impart a downward bias to the estimation of lessees' operating lease assets and liabilities. The overall impact on reported lease assets and liabilities based on 1999 data is summarised in Table 8, and the consequent effect on performance ratios in Table 9. 
Notwithstanding the radical nature of the assumption, operating lease assets and liabilities would remain a substantial feature on retail companies' balance sheets. The mean total operating lease liability estimates are $£ 94 \mathrm{~m}$ (food retailers), $£ 77 \mathrm{~m}$ (general retailers) and $£ 80 \mathrm{~m}$ (all), giving lease-debt ratios of $0.37,1.28$ and 0.82 , respectively. Overall, reported operating lease assets would represent approximately $11 \%$ of total assets. The impact on profit would also be slightly reduced but, across the retail sector overall, operating profit would still increase by about $9 \%$ and profit after tax would decrease by about $4 \%$; the impact on general retailers would continue to be slightly greater than on food retailers.

As expected, the size of the impact on performance ratios is also reduced, but the pattern and (statistical) significance of the median changes is almost identical. The one exception is the small reductions in median ROE, which are statistically significant but the size of the changes suggests low economic significance. Correlations between pre- and postcapitalisation ratios are higher than those reported in Table 5 and range between 0.22 and almost 1 . The margin, return and asset turnover ratios are now mainly above 0.9 , but interest cover and two of the three gearing ratios remain 'low'. For example, the Spearman rank correlation coefficient for the net debt to equity ratio is 0.53 (food) and 0.49 (general), and for gearing Ashton $_{\text {is }} 0.49$ (food) and 0.33 (general).

\section{$<$ TABLE 9 here >}

While the situation of maximum 5-year lease contracts modelled here may not be appropriate for some contracts, other 'opportunities' for mitigating the impact may well be available (e.g. the use of 'turnover rent' contingent rental contracts?). However, the above results suggest that, in the retail sector, lease capitalisation will probably have a fairly major impact on published financial statements and on performance ratios, even if company managers take steps to minimise the impact.

\section{Summary and conclusions}

The rights to use assets acquired under operating lease contracts are not currently recognised on the balance sheet of UK companies; rather, aggregate information about such contracts is disclosed by way of a note to the financial statements. Two G4+1 discussion papers have addressed the issue of off-balance sheet leases and the more recent of these, Leases: Implementation of a New Approach (ASB 1999), proposes that all leases should be recognised on the balance sheet. The objectives of the present paper are to document in a systematic way the importance of leasing in the UK retail sector and to estimate the potential balance sheet impact of the new accounting proposals. Unrecorded operating lease assets and liabilities were estimated using a 'constructive capitalisation' procedure for all retail companies. The impact of lease capitalisation was assessed by examining the effect on nine key accounting ratios that are used in decision-making and in financial contracts.

Operating lease finance was confirmed as a major source of finance in the retail sector. Indeed, the level of the off-balance sheet operating lease liability is much higher (3.3 times higher, overall) than the level of on-balance sheet debt. Thus, operating lease finance is significantly more important than long-term debt, an observation that is of major potential importance for users' assessment of financial risk. By contrast, finance leases are essentially immaterial, as indicated by the observation that operating lease liabilities are, on average, approximately 
37 times the level of finance leases. Operating lease assets represent a major proportion of reported total assets with estimates, based on overall means, of $16 \%$ for the food sub-sector, $37 \%$ for general and $28 \%$ overall. The majority of these assets relate to land and buildings ( $98 \%$ by value) rather than plant and equipment (2\%). The current exclusion of such assets from the balance sheet has the potential to distort return on asset type performance measures.

It is interesting to compare the above with some results from the US. Across all sectors over the period 1981 through 1992, Graham et al. (1998) provide evidence of an operating leasedebt ratio of approximately 0.6 (estimated from Table III: 140), compared with 3.3 for retail in the current study. Operating leases were 5 times as important as finance leases, compared with 37 times here. Yan (2002) provides data for 1997, which suggests that the US leasedebt ratio had increased to 0.7 and operating leases had increased in relative importance to 16 times finance leases (estimated from Table 1). In addition, Yan (2002) shows that the operating lease-debt ratio for the US retail sector in 1997 was 1.5, much higher than for other sectors (estimated from Table 3), but still lower than in the UK. Thus, operating leases are also a major source of finance to US retailers. The lower figure for the lease-debt ratio in the US reflects, at least partly, the shorter lease terms for US retail real estate (typically 510 years).

It is worth considering why operating lease finance is so prevalent in the retail sector. First, retail assets are relatively standard (city-centre shops, out-of-town shopping developments, offices and the like), which makes them generally more suitable for leasing than the more specialised assets often used in other industries. Second, the relatively low 'residual value' risk in retail assets makes them attractive to lessors for use in operating lease contracts. At the end of the operating lease the asset reverts back to the lessor. The residual value on reversion has to be estimated by the lessor at the start of the lease contract when determining the appropriate lease rentals. Errors in estimating residual values can cause considerable losses for lessors so the ready market in 'second-hand' retail assets, particularly in contrast with more specialised assets, is helpful. The residual value will depend on the likelihood that the asset can be re-let or sold by the lessor, and the state of the market for such assets at the date of reversion. The standardised nature of, for example, an out-of-town shopping development means that it is fairly simple to convert it, at relatively low cost, for use by a new lessee. Additionally, the considerable growth in out-of-town retailing in the UK has led to demand for such sites exceeding supply as a result of planning controls. Thus, there is likely to be a ready market for selling or re-letting the asset. Finally, typical lessors such as insurance companies and pension funds are looking for long-term investment growth and retail properties are among assets that, historically, have provided such growth.

The estimated impact of operating lease capitalisation on operating profit is an increase of about $23 \%$, on average, since the depreciation charged on leased assets will be less than the operating lease rentals. Profit after tax is expected to reduce by about $7 \%$. However, this fairly small average impact masks the fairly drastic effect that would be felt by some companies, notably those with very high levels of operating leases or with low levels of reported profit.

Capitalisation of operating leases would potentially have a major impact on all nine ratio measures of operating performance. This could have important economic consequences in decision contexts where performance is judged against an absolute benchmark, such as loan covenant restrictions or executive compensation schemes. In other decision contexts (such 
as investment decisions made by investors) the relative performance of companies is more relevant. The results show that the ranking of companies changes markedly for asset turnover, interest cover and the three capital-based gearing measures, and especially for general retailers. Results were shown to be robust with respect to key assumptions of the capitalisation method (i.e. discount rates, lease life estimates) and also over time.

Comparison with the earlier cross-sectoral study of BEG (1998) confirmed that retail companies are very heavy users of operating leases, with an overall mean operating lease liability 3.8 times higher than reported by BEG. The lease-debt ratio was over six times larger in the retail sector. Given this, the much greater impact on performance ratios in the retail sector is not surprising, but this does not diminish the amazing scale of the impact. For example, the large average cross-sectoral increase in net debt to equity of $260 \%$ reported by BEG is swamped by the $2246 \%$ increase in the retail sector.

One method by which managers might seek to minimise the impact of capitalisation is the use of renewable short lease contracts. The effect of one particular type of contract (i.e. a 'rolling five year' lease contract) for 'land and buildings' was also assessed. While this reduces the level of operating lease assets and liabilities, very significant amounts would still be reported on-balance sheet. The mean operating lease liability for the sector would still represent $82 \%$ of on-balance sheet long-term debt. All performance ratios continue to be significantly affected; for example, net debt to equity would increase from $16 \%$ to $57 \%$.

\section{Implications}

One of the main implications of the analysis is that ignoring operating leases in the assessment of retail companies is likely to distort inter-firm comparisons of performance, especially of financial risk. Users of financial statements need to be aware that often it can almost as difficult for a company to extricate itself from an operating lease contract as from an equivalent debt contract. But, unfortunately, the accurate estimation of assets and liabilities relating to operating leases is not straightforward. If the current proposals become standard accounting practice, there are likely to be major changes in company rankings, even if company managers act to counter the standard.

In the short-term, some have suggested alternative performance measures that might improve inter-company comparisons, in particular a measure of gearing based on the income statement, the 'fixed charge cover'. This measure is similar to the interest cover but it takes operating lease rentals into account. ${ }^{12}$ In the long-term, it is generally accepted that the accounting standard setters need to find an acceptable method of bringing lease assets and liabilities on balance sheet, but acceptability is likely to be the key issue.

An important question for both managers and investors is whether the introduction of a new accounting standard will affect the valuation of companies and their share price. The answer depends on whether the stock market is efficient in processing information. Some information about operating leases is already disclosed in the notes to company financial statements so investors and other users can make rough and ready estimates of total leased assets and liabilities. If this information is already captured by the market, then a requirement to capitalise all leases should have little impact on share prices. Indeed, there is some evidence from both the UK (Beattie et al. 2000b) and the US (Ely 1995; Imhoff et al. 1993) that share prices do take into account the extra risk that is implied in off-balance sheet operating leases. 
Notwithstanding this evidence, company managers are likely to seek to minimise the impact on companies' balance sheets. As suggested earlier, one approach would be to seek shorter lease terms. There is already commercial pressure from retail lessees to obtain more flexible (shorter) leases to reflect more closely their business needs (Nelson 1999). An impending accounting standard will add additional impetus in this direction.

The present results also imply that differences in the level of operating lease finance across national boundaries (see, for example, London Economics 2000: 46-8) will need to be incorporated in future cross-national differences in reported profitability and margins.

Finally, the results have major implications for researchers concerned with investigating company financing and capital structure decisions. Non-capitalised operating lease finance is an important source of finance and one whose usage varies across different companies and sectors. This implies that studies of capital structure that ignore operating leases can only provide a partial portrayal of corporate finance practice. 


\section{Notes}

${ }^{1}$ Taxation effects have been ignored here to simplify the argument. Under current tax rules, the amount of tax paid is not affected by the choice of accounting treatment. However, the tax charged in the profit and loss account will be lower in the early years of the lease, reflecting the lower profit before tax, and higher in the later years. The difference between tax paid and charged is accommodated by adjustments to deferred tax.

${ }^{2}$ An alternative approach to estimating the operating lease asset value has been adopted in the present paper (see BEG 1998: 243, footnote 9). The asset $\left(\mathrm{PV}_{\mathrm{A}}\right)$ and liability $\left(\mathrm{PV}_{\mathrm{L}}\right)$ values are related as follows: $\mathrm{PV} \mathrm{A}_{\mathrm{A}} / \mathrm{PV}_{\mathrm{L}}=$ $\left(\mathrm{RL} \times \mathrm{PVAF} \mathrm{F}_{\mathrm{i}, \mathrm{TL}}\right) /\left(\mathrm{TL} \times \mathrm{PVAF}_{\mathrm{i}, \mathrm{RL}}\right)$, where $\mathrm{RL}$ and $\mathrm{TL}$ are remaining and total lease lives, and $\mathrm{PVAF} \mathrm{F}_{\mathrm{i}, \mathrm{n}}$ is the present value of an annuity for $n$ years discounted at i\% (BEG 1998: 243, equation 8). In the BEG paper, the $\mathrm{PV}_{\mathrm{A}} / \mathrm{PV}_{\mathrm{L}}$ proportion was based on the historically weighted average RL and TL. In the present paper, the $\mathrm{PV}_{\mathrm{A}} / \mathrm{PV}_{\mathrm{L}}$ proportion is estimated for each expiry category, rather than using the overall average remaining and total lease lives. This approach reflects the current year position and is more appropriate for companies in which the historic average differs from the current balance between expiry categories. While this changes the estimated asset value for individual companies, as BEG report, the overall results are robust with respect to these alternatives.

${ }^{3}$ The remaining lease life estimates for the three expiry categories for 'land and buildings' are 1 year $(<1$ year expiry), 3 years (1-5 years expiry) and 16 years (> 5 years expiry); the equivalent total lease life estimates are 1,3 and 25 years respectively. For the 'other' category of assets, the remaining (total) lease life estimates are 1 (1), 3 (5) and 7 (10) years for the three expiry categories. The DKB study provides further support for the reasonableness of these assumptions. Given their analyst/broker relationship with companies, DKB were able to obtain estimates of average remaining lease life directly from companies. For 1999, these ranged between 5 and 48 years with four 'outlier' companies reporting remaining lives in excess of 40 years. Excluding these four outliers, the mean remaining lease life was 15 years (19 years including the outliers). Comparison of the median remaining life showed 13 in DKB against 14 in the present study, for companies common to both, suggesting that the estimates used here are reasonable. Lease liabilities will tend to bias downwards for the small number of companies having very long leases on their properties; i.e. the overall estimates will be slightly understated.

${ }^{4}$ The British Property Federation/Investment Property Databank Annual Lease Review (BPF/IPD 1999) also provides support for these assumptions. The average rent-weighted lease length of new leases over the period 1990-93 was 22.8 years. In more recent years, the lease life trend has been downwards; the average for new leases has fallen to 19.3, 18.5 and 16.4 years for 1994-5, 1996-7 and 1998-9 respectively. This downward trend will have some impact on the average life of 'land and buildings' leases for the retail companies in the study. However, these data are for new leases and, for many companies, a large proportion of their lease portfolio will have originated prior to the recent period in which lease lives have been falling. This may not be true for new companies in the sector and so there may be an element of upward bias in our estimates for new companies.

5 There were 3, 22 and 25 companies with zero long-term debt in food, general and the sector overall. Including these companies increased the observed median lease-debt ratios to 3.3, 39.6 and 29.2 respectively.

${ }^{6}$ There are several features of the data that cause difficulties in calculating or interpreting the performance ratios or changes therein. As a result, some companies had to be excluded from the analysis of ratios: (a) Four companies had negative equity in their reported financial statements (i.e. prior to capitalisation of operating leases) leading to problems with equity-based and asset-based ratios. Excluding these companies totally from further analysis led to sample sizes of 18 (food), 80 (general) and 98 (all). (b) Capitalisation of operating leases led to several additional companies having negative equity. These have been excluded only from the

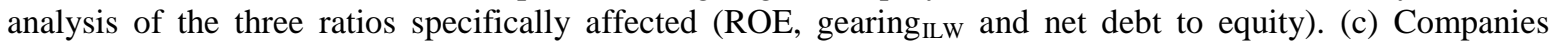
having zero interest in their reported financial statements are excluded from analysis of interest cover. This is necessary because it is not possible to calculate changes in interest cover since pre-capitalisation interest cover equals infinity. The notes at the foot of the Table 4 give full details of the numbers of companies excluded from analysis.

7 The use of a non-parametric test is more suitable given the non-normal distribution of many ratios (Barnes 1987). Despite the existence of uni-directional expectations for six of the ratios, for consistency two tailedtests were used throughout, leading to conservative reported significance levels for these ratios. 
${ }^{8}$ Several extreme outliers (defined as the quartiles $\pm 10 \times$ inter-quartile range) were identified in the ratio differences for interest cover ( 9 outliers) and the three ratios involving equity: ROE ( 9 outliers); gearing ILW $_{\text {( }}(3$ outliers) and net debt to equity ( 3 outliers). Excluding these extreme outliers, the mean differences between pre- and post-capitalisation ratios had identical signs and two-tailed t-stat significance to those reported for median differences. Including outliers, identical signs and significance were observed for seven ratios, but the mean difference for ROE was not significant and for interest cover was significant at the 5\% level.

${ }^{9}$ Mean differences were not statistically different for ROE, ROA, ROCE or interest cover, even after removal of the 2 extreme outliers for the interest cover ratio.

${ }^{10}$ The one exception here is the Pearson correlation coefficient for the net debt to equity gearing measure in the food retailing sub-sector; the coefficient is 0.57 and significantly above zero (at the $5 \%$ level).

${ }^{11}$ There was just one exception. While the difference in the ROE ratio for general retailers for 1994 was of the same sign and similar magnitude to the other years, it was not statistically significant.

${ }^{12}$ According to DKB (1998), the fixed charge cover was highlighted by Keith Hamill, WH Smith's finance director. Fixed charges include interest, operating lease rentals, and if available business rates and property taxes (though the latter two are not usually disclosed in the financial statements). The measure compares profit before fixed charges with fixed charges to give a more appropriate equivalent to interest cover. 


\section{References}

ASB (1999) Leases: Implementation of a New Approach, Discussion Paper, London: Accounting Standards Board.

ASB (2001) 2000 Annual review of the Financial Reporting Council. London: Accounting Standards Board.

ASC (1984) Accounting for Leases and Hire Purchase Contracts, Statement of Standard Accounting Practice No. 21, London: Accounting Standards Committee.

Ashton, R.K. (1985) 'Accounting for finance leases: a field test'. Accounting and Business Research, 15, Summer: 233-8.

Barnes, P. (1987) 'The analysis and use of financial ratios: a review article'. Journal of Business Finance \& Accounting, 14(4), Winter: 449-61.

Beattie, V.A., Edwards, K. and Goodacre, A. (1998) 'The impact of constructive operating lease capitalisation on key accounting ratios', Accounting and Business Research, 28(4), Autumn: 233-54.

Beattie, V.A., Goodacre, A. and Thomson, S. (2000a) 'Operating leases and the assessment of lease-debt substitutability', Journal of Banking \& Finance, 24 (3): 427-70.

Beattie, V.A., Goodacre, A. and Thomson, S. (2000b) 'Recognition versus disclosure: an investigation of the impact on equity risk using UK operating lease disclosures', Journal of Business, Finance \& Accounting, 27(9\&10), Nov/Dec: 1185-224.

BPF/IPD (1999) Annual Lease Review 1999, London: British Property Federation/Investment Property Databank.

Burt, S. and Sparks, L. (1997) 'Performance in food retailing: a cross-national consideration and comparison of retail margins', British Journal of Management, 8: 133-50.

Dresdner Kleinwort Benson (1998) Operating leases: the retail house of cards, London: Dresdner Kleinwort Benson Research.

Ely, K.M. (1995) 'Operating lease accounting and the market's assessment of equity risk', Journal of Accounting Research, 33(2), Autumn: 397-415.

Finance \& Leasing Association (1999) 'Think again Sir David: lease accounting reform is not as simple as you think', Press Release: 17 December, London: Finance \& Leasing Association.

Goodacre, A. and Beattie, V.A. (1999) 'Operating leases get the treatment', Professional Investor, October: 24-7.

Goodacre, A. (2001) 'The potential impact of enforced lease capitalisation in the UK retail sector', University of Stirling, Dept of Accounting, Finance and Law Discussion Paper DP $01 / 01$. 
Graham, J.R., Lemmon, M.L. and Schallheim, J.S. (1998) 'Debt, leases, taxes, and the endogeneity of corporate tax status', Journal of Finance, 53(1), February: 131-62.

Hutchinson, R.W. and Hunter, R.L. (1995) 'Determinants of capital structure in the retailing sector in the UK', The International Review of Retail, Distribution and Consumer Research, 5(1): 63-78.

Imhoff, E.A., Lipe, R.C. and Wright, D.W. (1991) 'Operating leases: impact of constructive capitalization’, Accounting Horizons, 5(1), March: 51-63.

Imhoff, E.A., Lipe, R.C. and Wright, D.W. (1993) 'The effects of recognition versus disclosure on shareholder risk and executive compensation', Journal of Accounting, Auditing and Finance, 8(4), Fall: 335-68.

Imhoff, E.A., Lipe, R.C. and Wright, D.W. (1997) 'Operating leases: income effects of constructive capitalization', Accounting Horizons, 11(2), June: 12-32.

Investment Property Forum (1999) 'Proposed capitalisation of operating leases - what impact on the UK property market?', Forum Review, Issue No. 3 October: 2-3.

KPMG (2000) 'Approach with caution', Financial Reporting Update, January/February: 12.

London Economics (2000) Rip-off-Britain: Myths and Realities, A report for the British Retail Consortium, London: London Economics.

McCaffery, K., Hutchinson, R. and Jackson, R. (1997) 'Aspects of the finance function: a review and survey into the UK retailing sector', The International Review of Retail, Distribution and Consumer Research, 7(2): 125-44.

McGregor, W. (1996) Accounting for Leases: A New Approach, Stamford, CT: Financial Accounting Standards Board.

Nelson, A.J. (1963). 'Capitalising leases - the effect on financial ratios', Journal of Accountancy, July: 49-58.

Nelson, F. (1999) 'Trouble in store for high street retailers', The Times, 4 December: 30-1.

O'Riordan, D. (1993) 'Retail gross margins: some international comparisons', International Journal of Retail and Distribution Management, 21(4): 33-9.

Parienté, S. (1994) 'Comparative profitability of large French and British retailers', The International Review of Retail, Distribution and Consumer Research, 4: 239-56.

Reither, C.L. (1998) 'What are the best and the worst accounting standards?', Accounting Horizons, 12(3), September: 283-92.

Retail Week (2000) 'BRC outraged at accounting blow', Retail Week, 14 April: 6.

Sainsbury (2000a) 'Sainsbury's to unlock stores' value in $£ 340$ million sale and leaseback deal', News release, 25 February. 
Sainsbury (2000b) 'Sainsbury's releases further value from store portfolio', News release, 25 July.

Sainsbury (2000c) J Sainsbury plc: Annual report and accounts 2000.

Sainsbury (2001) J Sainsbury plc: Annual Report and Financial Statements 2001.

Yan, A. (2002) 'Leasing and debt financing: substitutes or complements?', Working Paper, January, New York: Fordham University. 
Table 1

Accounting effects of alternative lease treatments for J Sainsbury plc transactions

Accounting treatment

Operating Finance Net

lease lease effect

Balance Sheet

A B $\quad$ B-A

Assets

Properties

Cost

Depreciation

Net book value

Cash

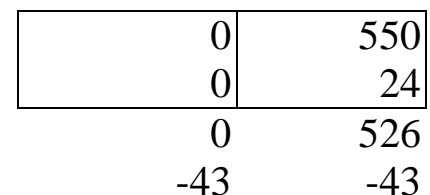

526

Liabilities

Lease rentals

Start of year

Interest for year

Amount paid

End of year

Net Assets

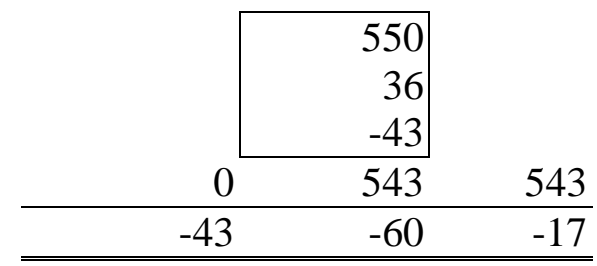

Shareholder's funds

Profit and loss account

$\begin{array}{lll}-43 & -60 & -17\end{array}$

Profit and loss account

Expenses

Operating lease rentals

Depreciation

Operating profit

Interest

Profit before tax

\begin{tabular}{rrr}
-43 & 0 & 43 \\
0 & -24 & -24 \\
\hline-43 & -24 & 19 \\
0 & -36 & -36 \\
\hline-43 & -60 & -17 \\
\hline
\end{tabular}


Table 2

The impact of capitalisation of operating leases on performance measures

\begin{tabular}{|c|c|}
\hline Performance measure & Impact of capitalisation \\
\hline \multicolumn{2}{|l|}{ Profit and loss effects } \\
\hline $\begin{array}{l}\text { Operating profit } \\
\text { [Earnings before interest and tax: EBIT] }\end{array}$ & $\uparrow$ \\
\hline Profit before tax & $\begin{array}{l}\downarrow \text { in early stages of lease } \\
\uparrow \text { in later stages of lease }\end{array}$ \\
\hline Profit after tax $[\mathrm{PAT}]$ & $\begin{array}{l}\downarrow \text { in early stages of lease } \\
\uparrow \text { in later stages of lease }\end{array}$ \\
\hline \multicolumn{2}{|l|}{ Balance sheet effects } \\
\hline Total assets [TA] & $\uparrow$ \\
\hline Debt & $\uparrow$ \\
\hline Equity (i.e. shareholders funds) [E] & $\downarrow$ \\
\hline \multicolumn{2}{|l|}{ Ratio effects } \\
\hline $\begin{array}{l}\text { Operating margin } \\
\text { [EBIT/Sales] }\end{array}$ & $\uparrow$ \\
\hline $\begin{array}{l}\text { Return on equity } \\
\text { [PAT/E] }\end{array}$ & uncertain \\
\hline $\begin{array}{l}\text { Return on assets } \\
\text { [PAT/TA] }\end{array}$ & $\downarrow$ \\
\hline $\begin{array}{l}\text { Return on capital employed } \\
\text { [EBIT /(TA less current liabilities)] }\end{array}$ & uncertain \\
\hline $\begin{array}{l}\text { Asset turnover } \\
\text { [Sales/(TA less current liabilities)] }\end{array}$ & $\downarrow$ \\
\hline $\begin{array}{l}\text { Interest cover } \\
\text { [EBIT/interest] }\end{array}$ & uncertain \\
\hline $\begin{array}{l}\text { Gearing: Ashton } \\
\text { [Debt: long-term/(TA less current liabilities)] }\end{array}$ & $\uparrow$ \\
\hline $\begin{array}{l}\text { Gearing: ILW } \\
\text { [Debt: total/E] }\end{array}$ & $\uparrow$ \\
\hline $\begin{array}{l}\text { Gearing: net debt to equity } \\
\text { [(Total borrowings less cash and equivalents)/E] }\end{array}$ & $\uparrow$ \\
\hline
\end{tabular}


Table 3

Estimated value of operating lease assets and liabilities for 1999

\begin{tabular}{|c|c|c|c|c|c|c|c|c|}
\hline & & \multicolumn{2}{|c|}{ Food $(n=20)$} & \multicolumn{2}{|c|}{ General $(n=82)$} & \multicolumn{2}{|c|}{ All $(n=102)$} & \multirow[b]{2}{*}{$\begin{array}{r}\text { Sainsbury } \\
£ m\end{array}$} \\
\hline & & $\begin{array}{r}\text { Mean } \\
£ m \\
\end{array}$ & $\begin{array}{r}\text { Median } \\
£ \mathbf{m} \\
\end{array}$ & $\begin{array}{r}\text { Mean } \\
£ m\end{array}$ & $\begin{array}{r}\text { Median } \\
£ \mathbf{m} \\
\end{array}$ & $\begin{array}{r}\text { Mean } \\
£ m \\
\end{array}$ & $\begin{array}{r}\text { Median } \\
\mathbf{£ m} \\
\end{array}$ & \\
\hline & \multicolumn{8}{|l|}{ BALANCE SHEET EFFECTS } \\
\hline \multirow{4}{*}{$\begin{array}{l}\text { A } \\
\text { B }\end{array}$} & \multicolumn{8}{|l|}{ Operating leases } \\
\hline & Liability due within 1 year & 13.4 & 3.5 & 12.2 & 2.8 & 12.4 & 2.8 & 94 \\
\hline & \multirow{2}{*}{$\begin{array}{l}\text { Liability due after more than } 1 \text { year } \\
\text { Total liability }\end{array}$} & 273.9 & 62.6 & 209.5 & 57.5 & 222.1 & 57.5 & 2240 \\
\hline & & 287.3 & 66.1 & 221.7 & 59.9 & 234.5 & 59.9 & 2334 \\
\hline $\mathrm{C}$ & Long-term debt (excl op leases) & 172.9 & 15.2 & 40.9 & 1.6 & 66.8 & 1.8 & 781 \\
\hline \multirow[t]{3}{*}{$\mathrm{A} / \mathrm{C}$} & Lease liability/debt ${ }^{1,2}$ & 1.58 & 2.87 & 5.12 & 9.11 & 3.32 & 6.64 & 2.87 \\
\hline & Lease asset: plant and equipment & 9.0 & 0.8 & 3.0 & 0.3 & 4.2 & 0.4 & 89 \\
\hline & Lease asset: land and buildings & 212.9 & 48.5 & 169.0 & 45.9 & 177.6 & 45.9 & 1710 \\
\hline $\mathrm{D}$ & Total lease asset & 221.9 & 51.3 & 172.0 & 46.0 & 181.8 & 46.0 & 1799 \\
\hline $\mathrm{E}$ & Total assets (excl op leases) & 1408.7 & 131.2 & 464.5 & 65.7 & 649.7 & 76.6 & 10050 \\
\hline \multirow[t]{4}{*}{$\mathrm{D} / \mathrm{E}$} & Lease asset/total asset ${ }^{2}$ & 0.16 & 0.34 & 0.37 & 0.55 & 0.28 & 0.52 & 0.18 \\
\hline & \multicolumn{8}{|l|}{ Finance leases (reported) } \\
\hline & Liability due within 1 year & 2.1 & 0.1 & 1.0 & 0.0 & 1.2 & 0.0 & 4 \\
\hline & Liability due after more than 1 year & 8.7 & 0.1 & 4.4 & 0.0 & 5.2 & 0.0 & 128 \\
\hline $\mathrm{F}$ & Total liability & 10.8 & 0.1 & 5.4 & 0.0 & 6.4 & 0.0 & 132 \\
\hline \multirow[t]{8}{*}{$\mathrm{B} / \mathrm{F}$} & Op leases/fin leases & 26.6 & & 41.1 & & 36.6 & & 17.7 \\
\hline & INCOME EFFECTS & & & & & & & \\
\hline & Operating profit (EBIT) reported & 147.4 & 14.5 & 51.5 & 9.9 & 70.3 & 10.5 & 944 \\
\hline & Operating profit post-capitalisation & 167.4 & 21.6 & 66.9 & 13.1 & 86.6 & 14.4 & 1106 \\
\hline & Percentage change $^{2}$ & 13.6 & 15.6 & 29.9 & 28.2 & 23.2 & 24.1 & 17.1 \\
\hline & Net profit (profit after tax) reported & 89.6 & 9.3 & 32.7 & 6.4 & 43.9 & 6.7 & 584 \\
\hline & Net profit post-capitalisation & 85.8 & 7.7 & 29.7 & 4.9 & 40.7 & 5.2 & 554 \\
\hline & Percentage change $^{2}$ & -4.2 & -5.1 & -9.2 & -8.4 & -7.3 & -7.7 & -5.1 \\
\hline
\end{tabular}

Notes

1. Several companies with zero long-term debt are excluded from the calculation: 3 (food), 22 (general), 25 (all).

2. Medians are based on lease liability/debt ratios and profit figures for individual companies. 


\section{Table 4}

\section{Changes in median ratios following lease capitalisation for 1999}

\begin{tabular}{|c|c|c|c|c|c|c|c|c|c|}
\hline & \multicolumn{3}{|c|}{ Food retailers ${ }^{1}$} & \multicolumn{3}{|c|}{ General retailers $^{1}$} & \multicolumn{2}{|c|}{ All retailers ${ }^{1}$} & \multirow[b]{2}{*}{$\operatorname{diff}^{2}$} \\
\hline & pre & post & $\operatorname{diff}^{2}$ & pre & Post & $\operatorname{diff}^{2}$ & pre & post & \\
\hline$\overline{P r o f i t ~ m a r g i n ~(\%) ~}$ & 4.3 & 5.7 & $1.4 * *$ & 8.1 & 11.5 & $3.4 * *$ & 7.7 & 10.7 & $3.0 * *$ \\
\hline Return on equity $(\%)^{3}$ & 13.1 & 13.5 & 0.4 & 14.4 & 17.0 & $2.6 * *$ & 13.7 & 16.1 & $2.4 * *$ \\
\hline Return on assets (\%) & 6.3 & 4.6 & $-1.7 *$ & 7.6 & 4.4 & $-3.2 * *$ & 7.3 & 4.5 & $-2.8 * *$ \\
\hline Return on capital employed (\%) & 17.3 & 14.7 & $-2.6 *$ & 21.1 & 15.2 & $-5.9 * *$ & 18.9 & 15.2 & $-3.7 * *$ \\
\hline Asset turnover & 3.2 & 2.3 & $-0.9 * *$ & 2.6 & 1.3 & $-1.3 * *$ & 2.8 & 1.4 & $-1.4 * *$ \\
\hline Interest cover ${ }^{4}$ & 9.4 & 2.9 & $-6.5 *$ & 11.0 & 2.2 & $-8.8 * *$ & 10.0 & 2.3 & $-7.7 * *$ \\
\hline Gearing $_{\text {Ashton }}(\%)$ & 11.3 & 61.4 & $50.1 * *$ & 5.1 & 69.2 & $64.1 * *$ & 5.4 & 67.7 & $62.3 * *$ \\
\hline Gearing $_{\mathrm{ILW}}(\%)^{5}$ & 109.9 & 306.3 & $196.4 * *$ & 86.8 & 285.6 & $198.8 * *$ & 89.4 & 286.1 & $196.7 * *$ \\
\hline Gearing (net debt to equity) $(\%)^{5}$ & 15.1 & 111.3 & $96.2 * *$ & 16.6 & 156.8 & $140.2 * *$ & 15.8 & 153.6 & $137.8 * *$ \\
\hline
\end{tabular}

Notes

1. With the general exclusion of 4 companies having negative equity pre-capitalisation, the results are for sample sizes of 18 (food), 80 (general) and 98 (all) except as indicated.

2. A two-tailed Wilcoxon signed ranks test of difference in medians (post - pre) $=0 ; * *(*)=$ significance at $1 \%(5 \%)$ level.

3. Excludes companies having negative equity post-capitalisation: 1 (food), 14 (general), 15 (all).

4. Excludes companies having no interest pre-capitalisation: 8 (general), 8 (all).

5. Excludes companies having negative equity post-capitalisation: 1 (food), 11 (general), 12 (all). For the last two gearing measures, deferred tax is effectively treated as a liability and, since capitalisation generally reduces deferred tax, overall debt is reduced. Further, equity is affected by the cumulative net of tax profit reduction. Thus, there are fewer companies having negative debt post-capitalisation than for the return on equity measure, which treats deferred tax as equity.

6. For comparison, pre (post) figures for J Sainsbury plc were: profit margin $=5.7 \%(6.7 \%)$; ROCE $=17.2 \%(15.4 \%)$; Gearing $_{\text {ILW }}=115.3 \%(175.3 \%)$; Gearing (net debt to equity) $=15.2 \%(70.9 \%)$. 
Table 5

Correlation between ratios pre- and post-operating leases capitalisation for 1999

\begin{tabular}{lccccccc}
\hline & \multicolumn{2}{c}{ Food retailers $^{1,2}$} & & \multicolumn{2}{c}{ General retailers } & & \multicolumn{2}{c}{ All retailers } \\
Spearman & Pearson & & Spearman & Pearson & & \multicolumn{2}{c}{ Spearman Pearson } \\
\hline Profit margin (\%) & 0.82 & 0.97 & 0.86 & 0.88 & 0.87 & 0.92 \\
Return on equity (\%) & 0.91 & 0.99 & 0.97 & 0.44 & 0.97 & 0.43 \\
Return on assets (\%) & 0.64 & 0.93 & 0.83 & 0.87 & 0.80 & 0.88 \\
Return on capital employed (\%) & 0.83 & 0.96 & 0.90 & 0.87 & 0.89 & 0.87 \\
Asset turnover & 0.65 & 0.67 & 0.47 & 0.55 & 0.52 & 0.51 \\
Interest cover $^{4}$ & 0.64 & 0.84 & 0.46 & 0.37 & 0.48 & $0.09 \mathrm{~ns}$ \\
Gearing $_{\text {Aston }}(\%)$ & $0.18 \mathrm{~ns}$ & $0.29 \mathrm{~ns}$ & $0.10 \mathrm{~ns}$ & $0.17 \mathrm{~ns}$ & $0.07 \mathrm{~ns}$ & $0.17 \mathrm{~ns}$ \\
Gearing $_{\text {ILW }}(\%)^{5}$ & 0.71 & 0.71 & 0.66 & $0.17 \mathrm{~ns}$ & 0.64 & $0.16 \mathrm{~ns}$ \\
Gearing (net debt to equity)(\%) $^{5}$ & $0.29 \mathrm{~ns}$ & 0.57 & $0.15 \mathrm{~ns}$ & $0.02 \mathrm{~ns}$ & $0.17 \mathrm{~ns}$ & $0.02 \mathrm{~ns}$ \\
& & & & & & \\
\hline
\end{tabular}

Notes

1. With the general exclusion of 4 companies having negative equity pre-capitalisation, the results are for sample sizes of 18 (food), 80 (general) and 98 (all) except as indicated.

2. $\mathrm{ns}=$ not significantly different from zero at $5 \%$ level (two-tailed) .

3. Excludes companies having negative equity post-capitalisation: 1 (food), 14 (general), 15 (all).

4. Excludes companies having no interest pre-capitalisation: 8 (general), 8 (all).

5. Excludes companies having negative equity post-capitalisation: 1 (food), 11 (general), 12 (all). For the last two gearing measures, deferred tax is effectively treated as a liability and, since capitalisation generally reduces deferred tax, overall debt is reduced. Further, equity is affected by the cumulative net of tax profit reduction. Thus, there are fewer companies having negative debt post-capitalisation than for the return on equity measure, which treats deferred tax as equity. 


\section{Table 6}

Comparison with other sectors: estimated mean value of operating lease assets and liabilities for 1994

\begin{tabular}{|c|c|c|c|c|}
\hline & & \multirow{2}{*}{$\begin{array}{r}\text { Present study } \\
\begin{array}{r}\text { All retail } \\
(\mathbf{n}=63)\end{array}\end{array}$} & \multicolumn{2}{|r|}{ BEG (1998) } \\
\hline & & & $\begin{array}{r}\text { Services } \\
(\mathbf{n}=\mathbf{8 1})\end{array}$ & $\begin{array}{r}\text { All sectors } \\
(\mathrm{n}=\mathbf{2 3 2})\end{array}$ \\
\hline & & $£ \mathbf{m}$ & $£ \mathbf{m}$ & $\mathfrak{£ m}$ \\
\hline & Operating leases & & & \\
\hline & Liability due within 1 year & 9.2 & 15.5 & 8.3 \\
\hline A & Liability due after more than 1 year & 185.7 & 87.9 & 42.5 \\
\hline B & Total liability & 194.9 & 103.4 & 50.8 \\
\hline $\mathrm{C}$ & Long-term debt (excl op leases) & 72.5 & 127.5 & 108.1 \\
\hline $\mathrm{A} / \mathrm{C}$ & Lease liability/debt & 2.56 & 0.69 & 0.39 \\
\hline $\mathrm{D}$ & Total lease asset & 146.7 & 79.8 & 39.9 \\
\hline $\mathrm{E}$ & Total assets (excl op leases) & 640.0 & 628.4 & 629.8 \\
\hline $\mathrm{D} / \mathrm{E}$ & Lease asset/total asset & 0.23 & 0.13 & 0.06 \\
\hline
\end{tabular}

Notes

1. This sub-sample represents the 63 retail companies, from the original sample of 102, that existed in 1994 (see comment in text concerning survivorship bias). A discount rate of $10 \%$ is used here for consistency with the BEG (1998) study.

2. The details for other sectors are extracted from Table 6, BEG (1998): 247. 
Table 7

\section{Comparison with previous studies on operating lease capitalisation}

Study

Sector covered

Country

Sample size

Financial statement year

\section{$\underline{\text { Present study }}{ }^{1}$}

All retailers

UK

$\mathrm{n}=98^{4}$

1999

\section{$\underline{\text { BEG (1998) }}{ }^{2}$}

All sectors

UK

$\mathrm{n}=232$

1994 $\underline{\text { ILW (1991) }}{ }^{3}$

Sundry

US

$\mathrm{n}=14$

1987

\section{Percentage change in mean ratio following capitalisation}

Profit margin $(\%)$

Return on equity (\%) 5

Return on assets (\%)

Return on capital employed (\%)

Asset turnover

Interest cover ${ }^{6}$

Gearing $_{\text {Ashton }}(\%)$

$\operatorname{Gearing}_{\text {ILW }}(\%)^{7}$

Gearing (net debt to equity) $(\%)^{8}$
$51.4 * *$

$35.1 * *$

$-44.8 * *$

$-32.8 * *$

$-55.2 * *$

$-79.3 * *$

$433.2 * *$

$295.0 * *$

$2246.0 * *$
$12.1 * *$

$4.8 *$

$-10.8 * *$

$-0.6$

$-12.5 * *$

$-25.9$

$92.8 * *$

$48.7 * *$

$260.0 * *$ na

na

na

na

na

na

119.0

na

Notes

1. Changes in means (rather than medians) are reported in this table for consistency with prior studies, but extreme outliers are removed to avoid distortions (see below for impact of outliers).

2. Figures reported in Table 8, BEG (1998): 249.

3. Derived from figures reported in ILW (1991): 61; no statistical tests of significance were reported.

4. Number of companies is 98 except for those ratios affected by negative equity, zero pre-capitalisation

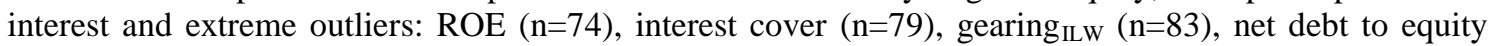
$(\mathrm{n}=83)$.

5. Including 9 outliers gave a percentage change of $61.3 \%$ in ROE.

6. Including 11 outliers gave a percentage change of $-98.3 \%$ in interest cover.

7. Including 3 outliers gave a percentage change of $517.5 \%$ in gearing ${ }_{\text {ILW }}$.

8. Including 3 outliers gave a percentage change of $4271.3 \%$ in net debt to equity.

9. na $=$ ratio not included in study

10. a two-tailed paired t-test for percentage change $=0$ : $* *(*)=$ significance at $1 \%(5 \%)$ level. 


\section{Table 8}

Effect of managers' response to lease capitalisation: estimated value of operating lease assets and liabilities for 1999 assuming re-negotiation of long contracts to renewable five-year terms

\begin{tabular}{|c|c|c|c|c|c|c|c|}
\hline & & \multicolumn{2}{|c|}{ Food $(n=20)$} & \multicolumn{2}{|c|}{ General $(\mathrm{n}=82)$} & \multicolumn{2}{|c|}{ All $(n=102)$} \\
\hline & & $\begin{array}{r}\text { Mean } \\
£ m\end{array}$ & $\begin{array}{r}\text { Median } \\
\text { fm }\end{array}$ & $\begin{array}{r}\text { Mean } \\
\text { fm } \\
\end{array}$ & $\begin{array}{r}\text { Median } \\
\text { fm }\end{array}$ & $\begin{array}{r}\text { Mean } \\
\text { fm } \\
\end{array}$ & $\begin{array}{r}\text { Median } \\
\text { £m }\end{array}$ \\
\hline & \multicolumn{7}{|l|}{ BALANCE SHEET EFFECTS } \\
\hline & \multicolumn{7}{|l|}{ Operating leases } \\
\hline & Liability due within 1 year & 29.8 & 7.2 & 24.5 & 5.9 & 25.5 & 5.9 \\
\hline A & Liability due after more than 1 year & 64.5 & 15.4 & 52.5 & 13.0 & 54.9 & 13.0 \\
\hline B & Total liability & 94.3 & 22.7 & 77.0 & 18.9 & 80.4 & 18.9 \\
\hline $\mathrm{C}$ & Long-term debt (excl op leases) & 172.9 & 15.2 & 40.9 & 1.6 & 66.8 & 1.8 \\
\hline \multirow[t]{3}{*}{$\mathrm{A} / \mathrm{C}$} & Lease liability/debt ${ }^{1}$ & 0.37 & 0.85 & 1.28 & 2.19 & 0.82 & 1.72 \\
\hline & Lease asset: plant and equipment & 7.2 & 0.8 & 2.9 & 0.3 & 3.8 & 0.3 \\
\hline & Lease asset: land and buidings & 80.1 & 18.5 & 68.5 & 17.4 & 70.7 & 17.4 \\
\hline $\mathrm{D}$ & Total lease asset & 87.3 & 21.0 & 71.4 & 17.5 & 74.5 & 17.5 \\
\hline $\mathrm{E}$ & Total assets (excl op leases) & 1408.7 & 131.2 & 464.5 & 65.7 & 649.7 & 76.6 \\
\hline \multirow[t]{4}{*}{$\mathrm{D} / \mathrm{E}$} & Lease asset/total asset ${ }^{2}$ & 0.06 & 0.14 & 0.15 & 0.22 & 0.11 & 0.20 \\
\hline & INCOME EFFECTS & & & & & & \\
\hline & Percentage change in operating profit ${ }^{2}$ & 5.3 & 20.7 & 12.2 & 8.1 & 9.4 & 9.5 \\
\hline & Percentage change in net profit ${ }^{2}$ & -1.9 & -7.5 & -4.6 & -7.8 & -3.6 & -10.5 \\
\hline
\end{tabular}

Notes

1. Median lease liability/debt ratio is based on individual company figures; several companies with zero long-term debt are excluded from the calculation: 3 (food), 22 (general), 25 (all).

2. Median lease liability/debt ratio is based on individual company figures. 
Table 9

Effect of managers' response to lease capitalisation: changes in median ratios following lease capitalisation for 1999 assuming re-negotiation of long contracts to renewable five-year terms

\begin{tabular}{|c|c|c|c|c|c|c|c|c|c|}
\hline & \multicolumn{3}{|c|}{ Food retailers ${ }^{1}$} & \multicolumn{3}{|c|}{ General retailers ${ }^{1}$} & \multicolumn{3}{|c|}{ All retailers ${ }^{1}$} \\
\hline & pre & post & $\operatorname{diff}^{2}$ & pre & post & $\operatorname{diff}^{2}$ & pre & post & $\operatorname{diff}^{2}$ \\
\hline Profit margin (\%) & 4.31 & 5.22 & $0.90 * *$ & 8.07 & 9.90 & $1.83 * *$ & 7.69 & 8.43 & $0.74 * *$ \\
\hline Return on equity $(\%)^{3,5}$ & 13.13 & 13.06 & $-0.07 * *$ & 16.39 & 16.17 & $-0.22 * *$ & 15.48 & 14.32 & $-1.16^{* *}$ \\
\hline Return on assets (\%) & 6.36 & 5.15 & $-1.21 *$ & 7.65 & 5.74 & $-1.91 * *$ & 7.28 & 5.42 & $-1.86 * *$ \\
\hline Return on capital employed (\%) & 17.33 & 17.11 & -0.22 & 21.06 & 18.98 & $-2.08 * *$ & 18.88 & 18.08 & $-0.80 * *$ \\
\hline Asset turnover & 3.24 & 2.83 & $-0.41 * *$ & 2.56 & 2.07 & $-0.49 * *$ & 2.78 & 2.24 & $-0.54 * *$ \\
\hline Interest cover ${ }^{4}$ & 9.43 & 4.79 & $-4.64 *$ & 11.01 & 3.43 & $-7.58 * *$ & 10.06 & 3.59 & $-6.48 * *$ \\
\hline Gearing $_{\text {Ashton }}(\%)$ & 11.28 & 29.72 & $18.44 * *$ & 5.14 & 32.55 & $27.41 * *$ & 5.37 & 32.29 & $26.92 * *$ \\
\hline Gearing $_{\text {ILW }}(\%)^{5}$ & 109.86 & 149.59 & $45.67 * *$ & 92.06 & 160.21 & $68.15 * *$ & 92.88 & 155.27 & $62.39 * *$ \\
\hline Gearing (net debt to equity) $(\%)^{5}$ & 15.16 & 50.87 & $40.79 * *$ & 16.26 & 61.03 & $44.77 * *$ & 15.56 & 57.16 & $41.60 * *$ \\
\hline
\end{tabular}

Notes

1. With the general exclusion of 4 companies having negative equity pre-capitalisation, the results are for sample sizes of 18 (food), 80 (general) and 98 (all) except as indicated.

2. $\quad$ diff $=$ post - pre; $* *(*)=$ significance at $1 \%(5 \%)$ level of two-tailed Wilcoxon signed ranks test of difference in medians.

3. Excludes companies having negative equity post-capitalisation: 1 (general), 1 (all).

4. Excludes companies having no interest pre-capitalisation: 8 (general), 8 (all).

5. The reduced number of general (and all) retailers having negative equity post-capitalisation gives increased sample sizes for these three ratios. In turn, this affects the pre-capitalisation ratios, which therefore differ from those reported in Table 4. 